Discussion Paper No. 07-056

\title{
Public Universities, Tuition and Competition - A Tiebout Model
}

Robert Schwager

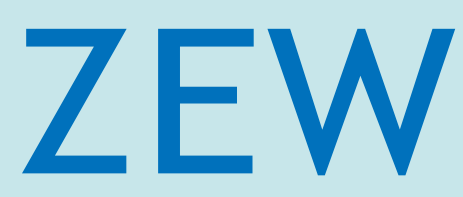

Zentrum für Europäische Wirtschaftsforschung $\mathrm{GmbH}$ Centre for European Economic Research 


\title{
Discussion Paper No. 07-056 \\ Public Universities, Tuition and Competition - A Tiebout Model
}

\author{
Robert Schwager
}

Download this ZEW Discussion Paper from our ftp server:

ftp://ftp.zew.de/pub/zew-docs/dp/dp07056.pdf

Die Discussion Papers dienen einer möglichst schnellen Verbreitung von neueren Forschungsarbeiten des ZEW. Die Beiträge liegen in alleiniger Verantwortung der Autoren und stellen nicht notwendigerweise die Meinung des ZEW dar.

Discussion Papers are intended to make results of ZEW research promptly available to other economists in order to encourage discussion and suggestions for revisions. The authors are solely responsible for the contents which do not necessarily represent the opinion of the ZEW. 


\section{Non-technical summary}

- A simple model is presented where states decide on, and finance, universities which are attended by local but also by non-resident, mobile students.

- The efficient allocation is characterised. By means of an example, it is shown that efficiency may require to concentrate mobile students in a small number of "elite" universities.

- Un-coordinated decisions by the states are shown to satisfy the same first order conditions as the efficient allocation provided that the universities have the right to charge a tuition fee reflecting the costs induced by an additional student.

- If tuition is banned or capped by the federal government, inefficient quality choices and insufficient admission numbers are likely to emerge.

- The analysis supports the assignment of responsibility for higher education to the Länder in the German federation. The right of the Länder to run universities should, however, be complemented by an unconstrained right to decide on tuition fees. 


\title{
Public Universities, Tuition and Competition - A Tiebout Model
}

\author{
by Robert Schwager \\ Georg-August-University Göttingen and \\ Centre for European Economic Research (ZEW), Mannheim
}

September 2007

\begin{abstract}
A simple Tiebout model is presented where states provide university education to both immobile and mobile students. State governments choose the quality of public universities by trading off the value of education for the local immobile student population and the costs, net of tuition revenues, of running the university. The quality of education and the assignment of students to universities in an efficient allocation are characterised. It is shown that decentralised decisions result in efficient choices if states are allowed to choose tuition levels freely. If tuition is capped, inefficiently low qualities are likely to arise.
\end{abstract}

JEL: H75, I28, H77

Keywords: higher education, migration, fiscal externality, club good, tuition

Acknowledgements. Part of this research was done while the author was visiting the Institute for Federalism and Intergovernmental Relations (IFIR) at the University of Kentucky. I am grateful for the hospitality I experienced there. I thank the participants of the Symposium 'Economics and Management of Education' at the University of Konstanz, June 29-30, 2007, for helpful comments and suggestions. Financial support by IFIR and the DFG (in the priority programme 1142 'Institutional Design of Federal Systems') is gratefully acknowledged.

\section{Address:}

Prof. Dr. Robert Schwager

Georg-August-Universität Göttingen

Wirtschaftswissenschaftliche Fakultät

Platz der Göttinger Sieben 3

37073 Göttingen

e-mail: rschwag@uni-goettingen.de 


\section{A. Introduction}

In recent years, the assignment of responsibilities for higher education between the German states (Länder) and the federation (Bund) has undergone several changes. This development started when the constitutional court voided, in two rulings issued in 2004 and 2005, ${ }^{1}$ two provisions amending the federal directive on universities (Hochschulrahmengesetz). The first of these provisions regulated the structure of personnel at state universities, and the second one stipulated that tuition fees are illegal. In both cases, the court ruled that the federation had no jurisdiction over the matter concerned, and hence strengthened the role of the states in higher education. In 2006, both chambers of parliament voted in favour of a set of changes to the vertical assignment of functions in the German federation. ${ }^{2}$ Included in this package was a decision to abolish the $50 \%$ matching grant so far provided by the federation to state investment in university buildings. ${ }^{3}$ In the same time, the states were granted more autonomy in running universities, a movement which meanwhile has culminated in a plan by the federal government to abolish the Hochschulrahmengesetz altogether. ${ }^{4}$

These developments have not been greeted with unequivocal welcome. Specifically, it is feared that un-coordinated competition in higher education leads to insufficient funding of universities. This opinion is based on a fiscal externality arising from the mobility of students across states. When a state government designs its universities, it will weigh the cost of education, paid out of the state budget, against the benefit procured by the university to the population of that state. This trade-off, however, does not include the benefits accruing to students who enter the state's universities but originate from other states. A state government which is responsible to the local electorate will disregard these benefits and hence, from a social point of view, will spend too little on universities. Similarly, the incentives to invest in higher education are reduced if part of the native high school graduates attend universities in other states. Büttner and Schwager (2004) provide empirical evidence showing that this fiscal externality is operating in the German federation. Using data on state expenditures for higher education, they find that a state spends less on universities if the neighboring states spend a lot. Thus, it seems that states whose high-school

\footnotetext{
${ }^{1}$ BVerfG, 2 BvF 2/02 vom 27.7.2004 and 2 BvF 1/03 vom 26.1.2005.

${ }^{2}$ This motion has become known as Föderalismusreform $I$. The laws enacting the reform are Gesetz zur Änderung des Grundgesetzes vom 28. August 2006, BGBl 2006, Teil I, Nr. 41, S. 2034, and Föderalismusreform-Begleitgesetz vom 5. September 2006, BGBl 2006, Teil I, Nr. 41, S. 2098.

${ }^{3}$ Gemeinschaftsaufgabe Hochschulbau, Art. 91a Abs. 1 Nr.1 GG a.F.; see BMF (2006), p. 87.

${ }^{4}$ See BMBF (2007).
} 
graduates can easily move or even commute to universities in other states drive down their own expenditures for higher education.

The objective of the present contribution is to put this empirical evidence, and the underlying fiscal externality argument, into a theoretical perspective. For this purpose, a standard fiscal competition model is presented. In this model, universities are run and paid for by sub-national governments out of tax revenues raised locally. There are both immobile and mobile students. Since state governments take only the interests of native students and taxpayers into account, neglecting the benefit of immigrant students, one might expect that the above mentioned under-provision of university education results. This is not the case, however, if universities have the right to raise tuition fees at a level which is at their discretion. It is shown that when this instrument is available, the willingness to pay for education by non-resident students is completely internalised in the state budget, and that by consequence, the Tiebout equilibrium is efficient.

A fiscal externality re-emerges, however, if the states do not have the right to choose the tuition level. If the federal government bans tuition, as was the case in the former Hochschulrahmengesetz, or more generally, fixes tuition fees at any arbitrary level, the states' decisions on the quality of higher education are distorted. If tuition is capped at a low level, it is likely that the quality of universities deteriorates, and that an insufficient number of students is admitted. The upshot of this analysis is that un-coordinated sub-national policies in higher education are not, by their nature, inefficient. Rather, any inefficiencies arise from an insufficient set of instruments in the hands of the states. In particular, the right to set tuition levels should complement the right to run universities.

The model presented here is rooted in the traditional theory of local public economics, pioneered by Tiebout (1956), and its non-spatial counterpart, the theory of clubs initiated by Buchanan (1965). Most previous applications of this approach in the field of education focus on primary or secondary education, rather than on universities like the present work. Correspondingly, in such models it is typically assumed that parents either move together with their children so as to enjoy a good public school financed out of local property taxes (for example, Miceli, 1993, and Nechyba, 1999), or that they pay tuition to a private profit maximising institution (for example, Epple and Romano, 1998). While this kind of work is motivated by US or British institutions, Büttner and Schwager (2004) and Kemnitz (2005) present models which are more closely tailored to the German system of financing higher education through state budgets. In Büttner and Schwager (2004), two states 
choose the qualities of their universities in the presence of student mobility, creating the fiscal externality described above. In this setup, the introduction of exogenous, small tuition fees is shown to locally improve the allocation. Since no decentralised tuition choice is modelled, however, it remains open in that paper to what extent tuition fees can restore efficiency.

Similar to the result presented here, Kemnitz (2005) shows that tuition fees improve educational quality when states are responsible for universities. Beyond several modelling details, the work by Kemnitz (2005) and the present paper mainly differ in the way the interest of native students is taken into account in the objective function of state governments. In Kemnitz's model, the earnings of these students are valued by state policy makers only insofar as they raise the state's tax revenues. Contrary to that, in the present model, native students' utilities enter the local objective function with the same weight as those of the taxpayers. Thus, the present paper pursues a more traditional welfare-economic approach, where the benefit of everyone in society counts, whereas the objective function in Kemnitz (2005) is rather motivated by public choice considerations, valuing only the interests of the majority of voters. It is remarkable, and strengthens the case for tuition fees in the context of decentralised education policies, that these two approaches reach a similar conclusion.

The present paper, and the work cited so far, deals with mobile incoming students. Another strand of literature considers students who attend university in their home region but move after graduation. Such mobility prevents states from recovering, through taxation of education-enhanced earnings, the public expenditures invested in their native students. In such a setting, as shown by Wildasin (2000), decentralised public provision of higher education is inefficient. Moreover, the structure of higher education is biased in favour of skills, such as legal studies, which are not internationally applicable (see Poutvaara, 2004, 2005). While this is clearly an interesting and relevant fiscal interaction, it is chiefly brought about by the fiscal competition for mobile (here, human) capital. In order to focus on the fiscal externality created by providing costly education to non-residents, this kind of fiscal competition is not considered in the present paper.

The rest of the paper is organised as follows. In section B, the model set-up is described. In section C, efficient allocations are characterised and illustrated by a numerical example. Decentralised policies are analysed in section D. There, the central result identifying Tiebout equilibria and efficient allocations is presented. Moreover, the impact of federally mandated tuition levels is examined and possible 
alternatives to tuition fees are discussed. The concluding section E discusses the implications of the results for higher education policy and the federal structure in Germany.

\section{B. The model}

The model describes a federation consisting of $J$ jurisdictions, called states, which are labelled $j=1,2, \ldots, J$. Each state provides tertiary education in a system of public universities. Individual universities are not modelled as separate actors. This is motivated by the fact that, in spite of a certain autonomy granted to public universities, these institutions are still largely under the control of state governments. In the following, the university system is consequently described, and referred to, as consisting of one university in each state. The university in state $j$ provides education at a quality $q_{j} \geq 0$. This variable captures all aspects of the university which are relevant for educational success, measured by the job prospects of graduates. For example, major determinants of quality may be the qualification of the faculty as researchers and teachers, the availability of books and computing facilities, the office hour time a teacher accords to each student, etc.

In state $j$, there are $\ell_{j}>0$ immobile, "local", students. They study in their home state and receive a wage $w_{\ell}\left(q_{j}\right)$ which depends on the quality of the education received. In addition, there are $M>0$ mobile students in the federation who can choose where to study. A mobile student who obtains her education in state $j$ will earn a wage of $w_{m}\left(q_{j}\right)$. Both functions $w_{\ell}$ and $w_{m}$ are increasing in quality, $w_{\ell}^{\prime}>0, w_{m}^{\prime}>0$, and concave, $w_{\ell}^{\prime \prime} \leq 0, w_{m}^{\prime \prime} \leq 0 .^{5}$

The fact that the wage functions $w_{\ell}$ and $w_{m}$ may differ means that the two groups of students are not only differentiated by their readiness to leave home, but also by characteristics relating to the educational success, such as academic ability or motivation. For example, mobile students may be more able academically than immobile students, so that they benefit more from whatever education is given to them. This may correspond to a society where it is the brightest or most energetic students who migrate, possibly because being confined to their home state would limit their

\footnotetext{
${ }^{5}$ This formulation ignores any consumption utility derived from studying at specific locations. While clearly, such considerations are relevant for many students (see Fabel et al., 2002), at least some mobile students seem to care about the academic quality of the university they attend (see Büttner et al., 2003). One could integrate such location specific attractions without altering the basic logic of the argument, for example by adding a state-specific leisure term to the wage function $w_{m}\left(q_{j}\right)$.
} 
intellectual and professional opportunities. In the converse case, where mobile students obtain a lower wage than local ones, mobility is related to a relatively inferior ability to take advantage of education. This might describe a student population who move away from home for lifestyle rather than academic reasons, such as to get away from the surveillance of parents, or to enjoy the attractions of big cities.

The cost of providing higher education in state $j$ depends on the quality $q_{j}$ which is supplied, and the number of students enrolled at the state's university. Total enrolment consists of the $\ell_{j}$ local students together with $m_{j}$ mobile students who study in state $j$. The cost function in state $j$ is given by $c^{j}\left(q_{j}, \ell_{j}+m_{j}\right)$. It is assumed to be convex, with first derivatives $c_{q}^{j}>0, c_{m}^{j}>0$ and second derivatives $c_{q q}^{j}>0, c_{m m}^{j}>0$, and $c_{q m}^{j} \geq 0$. This cost function describes how much money has to be spent in state $j$ if an education of quality $q_{j}$ is to be provided to $\ell_{j}+m_{j}$ students.

Naturally, costs increase in the quality of education. Moreover, costs also rise when more students are to be educated. Thus, the cost function displays crowding costs, as is common in Tiebout or club good models. In the context of a university, crowding costs arise when an increase in enrolment either directly induces a rise in public expenditures for the university, or indirectly makes additional costs necessary so as to maintain the quality. An example for the first case might be the costs for additional copies of teaching material which have to be provided to each student. An example for the second case is provided by the common experience of a classroom which becomes so crowded that it is difficult to follow the presentation of the instructor. The formulation used here implies that once quality is chosen, the government compensates any quality decline triggered in this way by an increase in the number of students. Thus, when classrooms are about to become overcrowded, the government will provide for new space and/or hire additional instructors so as to maintain the desired quality.

Mobile students obtain a utility $u_{o}$ if they do not study at all. Since in a decentralised setting, states may choose not to admit any mobile students, this is a relevant case, as will be seen in subsection D.II. In contrast, a no-study-option is not explicitly considered for the immobile students. Rather, its is assumed that in each state $j=$ $1,2, \ldots, J$, there is some (potentially small) quality level $q_{j}$ such that the aggregate net value of providing higher education to the local students, $\ell_{j} w_{\ell}\left(q_{j}\right)-c^{j}\left(q_{j}, \ell_{j}\right)$, is larger than their aggregate utility if they do not study. This essentially says that everywhere, at least some young people are able enough so that providing higher education to them is the best choice for society. ${ }^{6}$

\footnotetext{
${ }^{6}$ By this assumption, one avoids having to deal with the case where it is efficient for some state
} 
The model is closed by introducing a third group of individuals who are immobile, do not study, and have to pay, through their taxes, for the higher education provided in their home state. To use a convenient label, these agents are called the "parents". This group represents all agents in society who are not currently potential students. This includes both former students who now have reached working age ${ }^{7}$ and individuals who never study. Essentially, the role of the parents in the model is to provide the resources necessary to finance universities. The endowment of the parents in any state, although not explicitly modelled, is thus assumed to be, in each of the various scenarios analysed in sections $\mathrm{C}$ and $\mathrm{D}$, sufficiently large to pay for the costs of higher education provided in this state. ${ }^{8}$

\section{Efficient policies}

\section{First-order conditions}

Aggregate welfare is expressed, in monetary units, by the sum of the payoffs accruing to the three types of agents in all states. That is, welfare $W$ is given by the difference between the wages earned by immobile students and the wages or reservation utilities enjoyed by mobile students, and the provision costs incurred in all states. A Pareto efficient allocation is then characterised by the solution of the following optimisation problem: ${ }^{9}$

$$
\begin{array}{cc}
\max _{\left(q_{j}, m_{j}\right)_{j=1, \ldots, J}} & W\left(q_{1}, \ldots, q_{J}, m_{1}, \ldots, m_{J}\right)=\sum_{j} \ell_{j} w_{\ell}\left(q_{j}\right)+\sum_{j} m_{j} w_{m}\left(q_{j}\right) \\
& +\left(M-\sum_{j} m_{j}\right) u_{o}-\sum_{j} c^{j}\left(q_{j}, \ell_{j}+m_{j}\right) \\
\text { s.t. } \quad & M-\sum_{j} m_{j} \geq 0 \\
& m_{j} \geq 0 \text { for all } j=1,2, \ldots, J
\end{array}
$$

The constraints (2) and (3) require that in aggregate, at most the total number of mobile students can be enrolled somewhere, and that the number of mobile students

to close down its universities altogether - an outcome which is neither realistic nor interesting.

${ }^{7} \mathrm{With}$ this interpretation, the present set-up can be considered to be a shortcut for an overlapping generations model where young agents study and old agents pay taxes.

${ }^{8}$ The presence of immobile agents with "deep pockets" distinguishes the public university featuring in the present model from a private institution. A private university, even if it is not for profit, would have to break even, whereas any losses incurred by the public university can be covered by taxing immobile resources.

${ }^{9}$ Here and in the following, summations are taken over all states $j=1,2, \ldots, J$. 
in each state is non-negative.

Associating the Lagrange variables $\lambda$ to the constraint (2), and $\alpha_{j}$ to the nonnegativity constraint (3) applying to state $j$, the necessary conditions ${ }^{10}$ for an efficient allocation are, for $j=1, \ldots, J$,

$$
\begin{gathered}
\frac{\partial \mathcal{L}}{\partial q_{j}}=\ell_{j} w_{\ell}^{\prime}\left(q_{j}\right)+m_{j} w_{m}^{\prime}\left(q_{j}\right)-c_{q}^{j}\left(q_{j}, \ell_{j}+m_{j}\right)=0, \\
\frac{\partial \mathcal{L}}{\partial m_{j}}=w_{m}\left(q_{j}\right)-u_{o}-c_{m}^{j}\left(q_{j}, \ell_{j}+m_{j}\right)-\lambda+\alpha_{j}=0,
\end{gathered}
$$

together with the appropriate complementary slackness conditions. From equality (4) one derives the condition

$$
\ell_{j} w_{\ell}^{\prime}\left(q_{j}\right)+m_{j} w_{m}^{\prime}\left(q_{j}\right)=c_{q}^{j}\left(q_{j}, \ell_{j}+m_{j}\right)
$$

for an efficient quality $q_{j}$. At an efficient allocation the aggregate marginal willingness to pay for quality by all students enrolled in state $j$, local and mobile ones, is equated to the marginal cost of quality. This condition, which is reminiscent of the Samuelson condition for the efficient provision of a public good, illustrates the club good nature of higher education. Students can be excluded from using the university, so that only the willingness to pay of those who are admitted to state $j$ 's university is taken into account. Once admitted, however, all students benefit from the same quality, and hence their willingness to pay has to be added.

For a state $j$ which, in an efficient allocation, should admit a positive number $m_{j}$ of mobile students, one has $\alpha_{j}=0$. Thus, from (5), it follows

$$
w_{m}\left(q_{j}\right)-u_{o}-c_{m}^{j}\left(q_{j}, \ell_{j}+m_{j}\right)=\lambda .
$$

Similarly, if the efficient allocation requires that some state does not admit any mobile students, from $\alpha_{j} \geq 0$, one has

$$
w_{m}\left(q_{j}\right)-u_{o}-c_{m}^{j}\left(q_{j}, \ell_{j}\right) \leq \lambda
$$

with a strict inequality except for the borderline case where the non-negativity constraint (3) is just not binding. The left-hand sides in (7) and (8) give the net social benefit from educating an additional mobile student in state $j$. This benefit

\footnotetext{
${ }^{10}$ It is well known that in club good, or Tiebout, economies where the number of users of a public good is endogenous, standard convexity assumptions on preferences and technologies alone do not guarantee that first-order conditions are sufficient for a maximum (see, for example, Starrett, 1988, p. 77-83 and Schweizer, 1996). Since the present contribution is focussed upon the interpretation of Tiebout economies in the field of higher education, it is not attempted here to deal with this issue mathematically. Thus, only first-order conditions are considered.
} 
consists of the gain in wage procured to the student by studying in state $j$ rather than foregoing higher education, net of the marginal crowding cost inflicted by this student on the taxpayer in state $j$. Thus, according to (7), in an efficient allocation mobile students are allocated across space such that the net marginal benefit of educating them is equalised across all universities which do admit mobiles students. There may, however, be some universities which would provide a net benefit which is below this amount; according to (8), these universities should not admit any mobile students.

The level of the common net benefit $\lambda=w_{m}\left(q_{j}\right)-u_{o}-c_{m}^{j}\left(q_{j}, \ell_{j}+m_{j}\right)$ of educating mobile students is determined by their scarcity, measured by the shadow price $\lambda$. If $\lambda>0$, then $\sum_{j} m_{j}=M$. Thus, if it pays socially to educate mobile students at some university, then all students end up attending a university. Conversely, if some students do not attend university, $\sum_{j} m_{j}<M$, then for all students, the net benefit of higher education drops to zero.

The efficient inter-regional distribution of higher education institutions can display two qualitatively quite different patterns. On the one hand, mobile students might be distributed more or less evenly across states, with the quality of education in all states being similar, taking into account the interests of, and crowding costs induced by, the mobile students. Alternatively, the efficient university system in the federation may be very heterogeneous, with a few universities taking in all mobile students, whereas the remaining institutions cater to a purely local audience. In order to shed some light on the economic effects which cause one of these two scenarios to prevail, in the following subsection a simple example is presented which displays, for different parameter values, both kinds of solutions.

\section{An example}

In the example, there are two states, $J=2$, which are symmetric. In both states $j=1,2$ there is an equal number of local students $\ell_{j}=L / 2$, and the cost function is the same and given by

$$
c^{j}\left(q_{j}, \ell_{j}+m_{j}\right)=c\left(q_{j}, \frac{L}{2}+m_{j}\right)=\frac{1}{2} q_{j}^{2}+\frac{k^{2}}{2}\left(\frac{L}{2}+m_{j}\right)^{2} .
$$

In this cost function, the parameter $k \geq 0$ measures the importance of enrolmentrelated crowding costs. As seen from the cross derivative $c_{q m}=0$, an increase in the number of students has no impact on the marginal cost of quality. While clearly special, this case has an interesting interpretation. As mentioned in section B, 
quality of education is, among other things, also related to the scientific reputation of the faculty teaching at the university. Now it seems plausible that the marginal cost of enhancing reputation, say by hiring a star professor, is more or less the same in large and in small universities. Thus, the separable cost function (9) fits rather well the case where quality of education is mainly driven by the scientific qualification of the faculty.

For immobile students, the marginal wage impact of a better education is normalised to unity, so that $w_{\ell}\left(q_{j}\right)=q_{j}$. Mobile students obtain a wage given by $w_{m}\left(q_{j}\right)=w q_{j}$, where $w>0$ is a constant. Relating to the two types of mobile students discussed in section $\mathrm{B}, w>1(w<1)$ corresponds to a mobile student population which is more able (less able) than the immobile students.

In the following, two allocations are compared, an integrated allocation $(I)$ where in each state, half of the mobile students are enrolled, and a segregated $(S)$ one, where all mobile students gather in one jurisdiction, say state $1 .^{11}$ In the integrated allocation, the condition (6) for the optimal quality $q^{I}$ in each state reads $(L / 2) w_{\ell}^{\prime}\left(q^{I}\right)+(M / 2) w_{m}^{\prime}\left(q^{I}\right)=c_{q}\left(q^{I},(L+M) / 2\right)$. With $w_{\ell}^{\prime}=1, w_{m}^{\prime}=w$ and $c_{q}(q)=q$, this yields $q^{I}=(L+M w) / 2$. Inserting $q_{1}=q_{2}=q^{I}, \ell_{1}=\ell_{2}=L / 2$, and $m_{1}=m_{2}=M / 2$ in (1), one finds

$$
\begin{aligned}
W^{I} & =L \cdot w_{\ell}\left(q^{I}\right)+M \cdot w_{m}\left(q^{I}\right)-2 c\left(q^{I}, \frac{L+M}{2}\right) \\
& =\frac{1}{4}\left[(L+M w)^{2}-k^{2}(L+M)^{2}\right]
\end{aligned}
$$

for the welfare reached in an integrated allocation.

In the segregated allocation, the quality in state 1 , where all $M$ mobile students are enrolled, can be derived from the first order condition $(L / 2) w_{\ell}^{\prime}\left(q_{1}^{S}\right)+M w_{m}^{\prime}\left(q_{1}^{S}\right)=$ $c_{q}\left(q_{1}^{S},(L / 2)+M\right)$, yielding $q_{1}^{S}=(L / 2)+M w$. The quality in state 2 , where only local students are educated, follows from $(L / 2) w_{\ell}^{\prime}\left(q_{2}^{S}\right)=c_{q}\left(q_{2}^{S}, L / 2\right)$, and hence is $q_{2}^{S}=L / 2$. Using (1) again, the welfare

$$
\begin{aligned}
W^{S} & =\frac{L}{2} \cdot w_{\ell}\left(q_{1}^{S}\right)+M \cdot w_{m}\left(q_{1}^{S}\right)-c\left(q_{1}^{S}, \frac{L}{2}+M\right)+\frac{L}{2} \cdot w_{\ell}\left(q_{2}^{S}\right)-c\left(q_{2}^{S}, \frac{L}{2}\right) \\
& =\frac{1}{8}\left[(L+2 M w)^{2}-k^{2}(L+2 M)^{2}+\left(1-k^{2}\right) L^{2}\right]
\end{aligned}
$$

in the segregated allocation can be derived.

\footnotetext{
${ }^{11}$ For simplicity, in the example, the utility $u_{o}$ obtained by a mobile non-graduate is assumed to be so low that in an efficient allocation, all mobile students attend a university.
} 
Comparing both welfare levels from (10) and (11), one finds that

$$
W^{I} \geq W^{S} \quad \text { if and only if } \quad k \geq w
$$

Thus, in the example, both kinds of university landscape discussed in the end of subsection I can emerge as the efficient allocation, depending on the parameters $k$ and $w$. The integrated university system, where throughout the federation, universities cater to some mobile students and provide the same quality, is superior if (and only if) crowding costs in teaching are important, i.e., $k$ is high, and the mobile students are not very able compared to the immobile students, i.e., $w$ is low. Relating this result to the motivation for mobility discussed in section $\mathrm{B}$, the integrated university system seems to be specifically appropriate if student mobility is induced by lifestyle rather than by academic considerations, and if increasing numbers of such students strongly disrupt the education process. Conversely, if crowding costs are moderate and the wage premium for mobile graduates is high, a segregated university system appears to be best. If mobile students are motivated by academic ambition, and can expect a high return to a good education, then it may well be worthwhile, from a federation-wide point of view, to establish a very small number of high-quality ("excellent") universities in just a few states. All mobile students (the "elite"), will attend these universities, whereas the rest receive an education at their local university which is tailored to their moderate abilities.

This result obtains from the trade-off between crowding costs on the one hand, and the benefit from concentrating students on the other hand. High crowding costs suggest that one should avoid packing too many students in one university, and hence call for an even distribution of students across states. The benefit from concentrating students arises from a scale effect and from a specialisation effect. The larger the number of students enrolled in one university, the larger is the aggregate benefit derived from a given quality. Moreover, segregating all mobile students in one university allows to tailor the quality of education more closely to the specific demand of the two different groups of students. In the example, the higher the wage for mobile students, the more important it is to take advantage from scale and specialisation benefits. Thus, the benefit from concentration rises in the wage premium for mobile graduates. 


\section{Decentralised decisions}

\section{Tiebout equilibrium}

In this section, decentralised choices of higher education policies are examined and compared to the efficient allocation described in subsection C.I. Each state $j=$ $1, \ldots, J$ chooses the quality $q_{j}$ of its universities, the number $m_{j}$ of mobile students to be admitted, and a tuition fee $t_{j}$ charged to each student.

All mobile students are alike, and they can move without costs. Therefore, in an equilibrium, all of them must obtain the same utility level. Denoting this utility level by $u_{m}$, the fact that pursuing higher education is voluntary implies $u_{m} \geq$ $u_{o}$. Moreover, universities in state $j$ will only attract mobile students if the wage obtained after graduating from $j$ 's university, net of tuition, is at least as large as the utility obtainable otherwise. Thus, in order to be able to enrol a positive number $m_{j}>0$ of mobile students, state $j$ 's quality and tuition policies have to satisfy $w_{m}\left(q_{j}\right)-t_{j} \geq u_{m}$

State governments pursue the interest of their native population. This encompasses the wages of immobile students, $\ell_{j} w_{\ell}\left(q_{j}\right)$, net of tuition expenses paid by them, $\ell_{j} t_{j}$. Moreover, the state government represents the interests of immobile parents who bear the net fiscal burden induced by the university. This burden consists of the difference between tuition revenues from immobile and mobile students $\left(\ell_{j}+m_{j}\right) t_{j}$ and the operating costs of the university, $c^{j}\left(q_{j}, \ell_{j}+m_{j}\right)$. In the present analysis, states are considered to behave competitively, in the sense that a single state does not feel itself to be large enough to affect, by its decisions, the equilibrium utility $u_{m}$ of mobile students. This implies that the government of any state $j$, although it might be caring also for the mobile students originating from $j$, cannot affect, and hence does not have to take into account, the well-being of those students.

Aggregating the payoffs of the immobile students and the parents of state $j$, and observing that the tuition paid by immobile students cancels out, one obtains the maximisation problem of state $j$

$$
\begin{aligned}
\max _{q_{j}, t_{j}, m_{j}} & W_{j}\left(q_{j}, t_{j}, m_{j}\right)=\ell_{j} w_{\ell}\left(q_{j}\right)+m_{j} t_{j}-c^{j}\left(q_{j}, \ell_{j}+m_{j}\right) \\
\text { s.t. } & {\left[w_{m}\left(q_{j}\right)-t_{j}-u_{m}\right] m_{j} \geq 0, } \\
& m_{j} \geq 0 .
\end{aligned}
$$


Here, condition (15) rules out negative numbers of mobile students, and constraint (14) ensures that mobile students are willing to apply to the university in $j$ if a positive number $m_{j}>0$ is to be admitted.

An equilibrium consists of a vector of qualities, tuition fees, and admission policies for all states, $\left(q_{j}, t_{j}, m_{j}\right)_{j=1}^{J}$, and a utility level $u_{m} \geq u_{o}$ for mobile students such that $\left(q_{j}, t_{j}, m_{j}\right)$ solves state $j$ 's maximization problem (13) to (15), and such that in aggregate, states do not admit more than the total number of students, $M-$ $\sum_{j=1}^{J} m_{j} \geq 0$. In addition, optimality of the mobile students' decision requires $\sum_{j=1}^{J} m_{j}=M$ if $u_{m}>u_{o}$ and $u_{m}=u_{o}$ if $\sum_{j=1}^{J} m_{j}<M$. Thus, if higher education is worthwhile for a student, every student is admitted at some university. Conversely, if there are students who choose not to pursue university education, the utility of mobile graduates is driven down to the utility level of non-graduates.

In order to solve the maximisation problem (13) to (15), the Lagrange multipliers $\mu_{j}$ and $\alpha_{j}$ are associated to the constraints (14) and (15) respectively. Then, the necessary conditions for an optimum are

$$
\begin{aligned}
\frac{\partial \mathcal{L}}{\partial q_{j}}=\ell_{j} w_{\ell}^{\prime}\left(q_{j}\right)-c_{q}^{j}\left(q_{j}, \ell_{j}+m_{j}\right)+\mu_{j} m_{j} w_{m}^{\prime}\left(q_{j}\right) & =0, \\
\frac{\partial \mathcal{L}}{\partial t_{j}}=m_{j}-\mu_{j} m_{j} & =0, \\
\frac{\partial \mathcal{L}}{\partial m_{j}}=t_{j}-c_{m}^{j}\left(q_{j}, \ell_{j}+m_{j}\right)+\mu_{j}\left[w_{m}\left(q_{j}\right)-t_{j}-u_{m}\right]+\alpha_{j} & =0,
\end{aligned}
$$

together with the complementary slackness conditions corresponding to the constraints (14) and (15).

Considering first the case where the state wants to admit mobile students, $m_{j}>0$, one observes from (17) that $\mu_{j}=1$. Inserting in (16) leads to the efficiency condition (6). Thus, conditional on the number of mobile students, a state chooses the efficient quality. Moreover, from complementary slackness and $m_{j}>0, \mu_{j}>0$, it follows that

$$
w_{m}\left(q_{j}\right)-t_{j}=u_{m}
$$

Thus, a state which admits mobile students to its universities will raise tuition so high that the package composed of quality and tuition is just attractive enough to get applications. Moreover, with $m_{j}>0$, one must also have $\alpha_{j}=0$. Using this together with (19) in (18), one obtains

$$
t_{j}=c_{m}^{j}\left(q_{j}, \ell_{j}+m_{j}\right)
$$


An additional student is thus charged the marginal crowding cost he inflicts on the provider. Combining (20) with (19), one finally arrives at

$$
w_{m}\left(q_{j}\right)-c_{m}^{j}\left(q_{j}, \ell_{j}\right)=u_{m} .
$$

Thus, in an equilibrium, the net social benefit of educating an additional student in state $j$ is equal to the utility this student obtains elsewhere.

In the case $m_{j}=0$, condition (16) again reduces to the efficiency condition (6), with only local students determining the quality in this case. Moreover, since anyway, no mobile student is admitted, the choice of the tuition level is not determined in an optimum. Consequently, also in this case, the tuition level can be set equal to marginal crowding costs, $t_{j}=c_{m}^{j}\left(q_{j}, \ell_{j}\right)$, without reducing the value of the objective function. Moreover, as seen from (17), also the value of the Lagrange variable $\mu_{j}$ is not determined if $m_{j}=0$. Choosing a positive value $\mu_{j}>0,(18)$ then reduces to

$$
w_{m}\left(q_{j}\right)-c_{m}^{j}\left(q_{j}, \ell_{j}\right)-u_{m}=-\frac{\alpha_{j}}{\mu_{j}} \leq 0
$$

with a strict inequality except for the limiting case where the non-negativity constraint (15) is just not binding. Therefore, if $m_{j}=0$ is optimal, the net social benefit of admitting a student to the university in state $j$ must be less than the utility achievable for mobile students at other places or without university education.

To show that an efficient allocation can be supported as a Tiebout equilibrium, it remains to show that there is a utility level $u_{m}$ obtained by mobile students in the equilibrium such that the conditions (21) and (22) determining decentrally optimal enrolment coincide with the corresponding conditions for the welfare maximising assignment of students to universities, (7) and (8). This is achieved with $u_{m}=\lambda+u_{o}$. That is, the equilibrium utility level $u_{m}$ is chosen to be equal to the sum of the value of education in the efficient allocation, $\lambda$, plus the utility $u_{o}$ obtained by a mobile student if she foregoes higher education. With this equilibrium utility level, the efficient choices are also optimal for the states. Finally, the solution to the welfare maximisation problem implies that all mobile students are enrolled at some university if $\lambda=u_{m}-u_{o}>0$. Conversely, if it is efficient to leave some mobile students without higher education, then $\lambda=u_{m}-u_{o}=0$.

To summarise, the analysis in this subsection has shown that there is no market failure intrinsic to a decentralised provision of higher education. This is true in spite of the fact that state governments do not care about the utility of immigrating students who take advantage of the quality of education provided by local taxpayers. The main institutional requirement for this result to obtain is that states are free 
to choose a tuition level which adequately reflects the cost of providing university education. In the following, it is examined how the equilibrium is affected if this requirement is not met.

\section{Federal regulation}

In order to account for this kind of institutional restriction, in the present subsection, the central government fixes tuition levels at some arbitrary values $\bar{t}_{j}$ for all states $j=1,2, \ldots, J$, which the states are not allowed to exceed nor undercut. The federally mandated tuition levels need not be uniform across states. For example, it is conceivable that federal policy makers, for equity reasons, wish to impose lower

tuition fees in East Germany. Moreover, no specific level of the values $\bar{t}_{j}$ is assumed, although the politically relevant case clearly is given by a tuition cap which, for social policy reasons, is rather low.

With predetermined tuition level $\bar{t}_{j}$, state $j$ only decides on quality and enrolment. Thus, its decision problem (13) to (15) changes to

$$
\begin{array}{ll}
\max _{q_{j}, m_{j}} & W_{j}\left(q_{j}, \bar{t}_{j}, m_{j}\right)=\ell_{j} w_{\ell}\left(q_{j}\right)+m_{j} \bar{t}_{j}-c^{j}\left(q_{j}, \ell_{j}+m_{j}\right) \\
\text { s.t. } & {\left[w_{m}\left(q_{j}\right)-\bar{t}_{j}-u_{m}\right] m_{j} \geq 0} \\
& m_{j} \geq 0 .
\end{array}
$$

The necessary conditions for an optimum are

$$
\begin{aligned}
\frac{\partial \mathcal{L}}{\partial q_{j}}=\ell_{j} w_{\ell}^{\prime}\left(q_{j}\right)-c_{q}^{j}\left(q_{j}, \ell_{j}+m_{j}\right)+\mu_{j} m_{j} w_{m}^{\prime}\left(q_{j}\right) & =0, \\
\frac{\partial \mathcal{L}}{\partial m_{j}}=\bar{t}_{j}-c_{m}^{j}\left(q_{j}, \ell_{j}+m_{j}\right)+\mu_{j}\left[w_{m}\left(q_{j}\right)-\bar{t}_{j}-u_{m}\right]+\alpha_{j} & =0,
\end{aligned}
$$

with the complementary slackness conditions on both restrictions.

Also with fixed tuition level, state $j$ may optimally choose to admit mobile students $\left(m_{j}>0\right)$ or not $\left(m_{j}=0\right)$. In a solution with $m_{j}>0$, one has $\alpha_{j}=0$ and $\mu_{j}\left[w_{m}\left(q_{j}\right)-\bar{t}_{j}-u_{m}\right]=0$. This implies with (27) that (20) holds for $t_{j}=\bar{t}_{j}$. That is, admission is chosen so that the predetermined tuition just covers marginal crowding costs. Regarding the quality of the university in state $j$, two scenarios can emerge. Firstly, like in the case with unconstrained tuition, it is possible that the migration constraint (24) is binding so that (19) holds with $t_{j}=\bar{t}_{j}$. In the case of a fixed tuition, this equation alone determines the quality $q_{j}$. That is, if the state cannot 
adjust the tuition level so as to extract the rent from mobile students, it will achieve the same result by reducing the quality of the education. Consequently, the efficiency condition (6) does not govern the quality choice anymore. Instead, equation (26) gives the value of the Lagrange multiplier

$$
\mu_{j}=\frac{c_{q}^{j}\left(q_{j}, \ell_{j}+m_{j}\right)-\ell_{j} w_{\ell}^{\prime}\left(q_{j}\right)}{m_{j} w_{m}^{\prime}\left(q_{j}\right)},
$$

where $q_{j}$ is determined by (19) with $t_{j}=\bar{t}_{j}$, and $m_{j}$ is then determined, using $q_{j}$, by (20). Since $\mu_{j}$ must not be negative, this solution arises if

$$
c_{q}^{j}\left(q_{j}, \ell_{j}+m_{j}\right)-\ell_{j} w_{\ell}^{\prime}\left(q_{j}\right) \geq 0 .
$$

If the values $q_{j}, m_{j}$ determined from (19) and (20) fail to satisfy (29), then the second scenario applies, where a positive rent is left to the mobile students, $w_{m}\left(q_{j}\right)-\bar{t}_{j}>u_{m}$. This requires $\mu_{j}=0$, and hence in this case, from (26), one derives

$$
\ell_{j} w_{\ell}^{\prime}\left(q_{j}\right)=c_{q}^{j}\left(q_{j}, \ell_{j}+m_{j}\right)
$$

for the quality $q_{j}$. Just as in the efficiency condition (6), the state government takes into account the impact of mobile students on the marginal cost of providing quality. It disregards, however, the willingness to pay for quality by the mobile students.

Which one of these solutions arises depends on the level of the tuition $\bar{t}_{j}$. If tuition is very low, a low quality $q_{j}$ will be sufficient to attract applications by mobile students. Such a low quality, however, will be too low from the point of view of the local students, i.e., (29) fails. Then, it is preferable for the state $j$ to increase quality, even if this leaves some rent to the mobile students. Conversely, if the tuition is very high, a high quality will be needed to make mobile students ready to study in state $j$. Then, (29) will hold, and the state, in order to attract lucrative immigrant students, pays for a quality which exceeds the one which would be best for the local students.

In both cases, with fixed tuition, the quality choice is distorted. Except for the coincidental case where $\mu_{j}=1$, the condition (6) is violated. It should be noted that this result is independent of the level of the federally imposed tuition $\bar{t}_{j}$. Even if $\bar{t}_{j}$ is rather high, the benefit of an increase in quality accruing to mobile students is not valued correctly by the state government, since it is not allowed to adjust tuition accordingly. Thus, in contrast to a common complaint issued by representatives of universities, the distortion of quality is not exclusively due to insufficient funding. Rather, it is the consequence of a mismatch in the assignment of decisions and revenues across layers of the public sector. 
Turning now to the case where it is optimal for state $j$ not to admit any mobile students, $m_{j}=0$, then from (26), the locally optimal quality $q_{j}$ will be chosen according to the efficiency condition (6) with $m_{j}=0$. Such a solution can arise if, with this quality $q_{j}$, either $w_{m}\left(q_{j}\right)-\bar{t}_{j}-u_{m} \leq 0$, or $\bar{t}_{j}-c_{m}^{j}\left(q_{j}, \ell_{j}\right) \leq 0$, or both. If both of these inequalities hold, it follows $w_{m}\left(q_{j}\right)-c_{m}^{j}\left(q_{j}, \ell_{j}\right)-u_{m} \leq 0$. Thus, in this case, educating a mobile student in state $j$ would provide a net social benefit which falls short of the utility which this student can expect elsewhere, and would therefore be socially wasteful. With an arbitrary tuition $\bar{t}_{j}$, it may also be that no mobile students are enrolled at the university in state $j$ although it would be efficient to do so. This may occur if one has $w_{m}\left(q_{j}\right)-\bar{t}_{j}-u_{m}<0$ and $\bar{t}_{j}-c_{m}^{j}\left(q_{j}, \ell_{j}\right) \geq 0$ or $w_{m}\left(q_{j}\right)-\bar{t}_{j}-u_{m} \geq 0$ and $\bar{t}_{j}-c_{m}^{j}\left(q_{j}, \ell_{j}\right)<0$. The first case corresponds to a tuition level which is set too high. The state is willing to admit some mobile students, but these do not apply because the education provided is not worth the tuition. In the second case, which corresponds to a tuition cap which is set fairly low, mobile students are happy to apply to the university in state $j$ but admitting them does not pay off for the state.

Collecting the arguments from the previous discussion, and focussing on the realistic case of a low tuition level, it appears likely that in the nationwide equilibrium, some mobile students are not admitted to any university, while others are. At the same time, in order to satisfy the needs of the local students, states will provide a quality which is better than the one necessary to attract mobile students. Thus, some mobile students will have to part without education, and some will obtain an education which provides them with a rent, making them strictly better off than those who are rejected by all universities.

A federally mandated tuition level thus creates a fiscal externality which is not present when states are allowed to choose tuition levels freely. This externality works in two dimensions. With a fixed tuition, there is no flexible price signal relating the benefit of mobile students to quality improvements performed by state governments, and so quality is distorted. Moreover, if tuition is capped at a low level, states are reluctant to admit mobile students because they are not compensated for the crowding costs induced by increasing numbers of students. As a consequence, a university landscape emerges which, at a certain level of abstraction, is reminiscent of the German experience throughout the last three decades: The quality of education is chosen rather low, without taking into account the benefit of mobile students; there is a permanent shortage of university places; and student applications have to be rationed. 


\section{Alternative fiscal instruments}

For the sake of analytical clarity, the formal model presented so far considers only a restricted set of fiscal instruments, i.e., tuition fees and a lump sum tax on immobile residents. In order to interpret the results in a policy-oriented discussion, the present subsection enlarges the focus by taking other fiscal instruments into account. Specifically, it will be discussed how taxes paid by graduates and inter-governmental transfers might interfere with the efficiency result obtained in subsection I.

For the discussion of income taxes paid by graduates, it is worthwhile to distinguish between taxation by the federation and by the states. A federal tax reduces the net income of graduates. If tuition is not deductible from the tax base, such a tax makes it less attractive to take up university education. In the same time, the revenue collected at most partially ${ }^{12}$ accrues to the state government, and thus only part of it can be used to improve the university provided by the state. As a result, a federal income tax is likely to reduce the overall quality of higher education. While this vertical fiscal externality is a matter of concern, it is somewhat peripheral to the issue of inter-state migration which is at the heart of the present paper. The reason is that a uniform federal tax will reduce incentives to study in all states in a similar way. ${ }^{13}$ Thus, the federal tax will reduce human capital accumulation, but will not strongly distort its inter-regional allocation.

Contrary to a federal tax, the revenues of a state income tax paid by graduates will fully accrue to the states and thus can be used to finance universities. Moreover, when the state has autonomy over the tax schedule, it can choose the tax rate so as to reflect the marginal crowding costs of educating an additional student. Mobile students will then choose the university which provides the highest income net of taxes, rather than net of tuition fees. This shows that, in the structure described by the model, a state income tax paid by graduates is equivalent to the tuition fee. Implementing this tax in practice, however, could be difficult for at least two reasons. Firstly, in order to provide the right incentives for students, the tax cannot be designed as a general income tax, where only the level, but not the source of income matters for the tax liability. Rather, the tax bill of a graduate would have to exceed the one of a non-graduate with the same income by the marginal cost of education. It is reasonable to expect that Germany's constitutional court would rule such a differentiation to be unconstitutional on the grounds that it violates

\footnotetext{
${ }^{12}$ In Germany, states obtain $42.5 \%$ of income tax revenues (Art. 106 Abs. 3 S. 2, Abs. 5 GG).

${ }^{13}$ Some second order effects may arise from a progressive tax schedule since students are disproportionately discouraged from attending high quality universities.
} 
horizontal equity. Secondly, and more fundamentally, students would simply evade the graduate tax by moving to a low-tax state after graduation. ${ }^{14}$ To overcome this, states where graduates work would have to collect graduate taxes on behalf of the states which have provided the education. Since no state has an incentive to administer a tax whose revenues accrue to others, a federal clearing and enforcement mechanism would be needed - a rather cumbersome and dispute-prone institution. The upshot of this discussion is that, although equivalent in a narrow theoretical setting, a graduate tax which is levied ex post is much more difficult to implement than a tuition fee which is paid ex ante.

Instead of the individual student paying tuition, the government of her home state could pay an equivalent amount to the state where the student takes up higher education. Such a system has been suggested for Germany under the name of "GefoS" ${ }^{\prime 15}$, and is used in Switzerland. It creates the right incentives for state governments as long as they take into account the benefit accruing to emigrating students. Students, however, would not care about the transfer paid by their home state and thus would choose the best universities, regardless of the cost of education. In order to avoid this, students themselves would have to bear differences in tuition levels at the margin. A way to achieve this is offered by vouchers. According to this idea, each high school graduate obtains a voucher representing a certain amount of tuition fees, and is free to choose whether and where to study. Once a student takes up higher education in another state than her home state, the home state transfers the amount guaranteed by the voucher to the university where the student is enrolled. If this is a high quality institution charging more than the voucher, the student would have to top up the voucher. Conversely, a student who is satisfied to attend a low quality university, or none at all, should be allowed to cash in the difference between the voucher and the tuition charged. In essence, a voucherbased intergovernmental transfer system is thus a lump sum subsidy paid to mobile students by the taxpayers of the home state.

\footnotetext{
${ }^{14}$ This effect is at the heart of Wildasin's (2000) inefficiency result. The analysis presented here suggests that an autonomy to set tuition fees at the university level will restore efficiency even in Wildasin's context of mobile graduates. The proof of this claim is left for future work, or to the reader.

15 "Geld folgt Studierenden" (Money follows students), see CHE and Stifterverband (1998, 1999).
} 


\section{E. Conclusion}

In this paper, a standard Tiebout model has been applied to higher education. It was shown that an efficient allocation can be decentralised to states competing for mobile students, provided that the states have the right to choose tuition fees according to crowding costs. When such fees are ruled out by federal legislation, states are likely to run down the quality of universities and to provide too few places for students.

From this result, one concludes that the abolition of the ban on tuition fees forced by the constitutional court in its 2005 ruling is a step in the right direction. Specifically, tuition fees are an essential part of a decentralised system of providing higher education, as we have it in Germany. In order to get an idea about the likely level of the tuition fee required, a look at actual expenditures per student is worthwhile. A first benchmark for such a figure is obtained by simply dividing total expenditures for higher education by the number of students enrolled. For example, relating the amount spent in 2005 by German higher education institutions in the fields of law, business/economics, and the social sciences, to the number of students enrolled in these fields during the winter term 2005/06, one arrives at expenditures per student of $€ 2547 .{ }^{16}$ A much more sophisticated approach has been followed by Lüdeke and Beckmann (1998) who, in addition to current outlays, assess imputed rents for university buildings and implicit pension liabilities for professors. These authors estimate the annual cost of educating a student in the social sciences to be $€ 5581$ in prices of 1994; for some other fields like theology and medical studies, they find substantially higher costs. ${ }^{17}$ Their approach does not distinguish, however, between average and marginal crowding costs. This is attempted in Kraus (2004). Using data on current expenditures for the years 1996-1999 from all business/economics departments in Germany, Kraus estimates the marginal cost of an additional student in these fields, evaluated at the enrolment size which minimises cost per student, at $€ 1799$ p.a. Although the wide variation of these numbers obviously leaves a lot of room for interpretation, it seems plausible that the maximal tuition fee of € 1000 currently levied falls short of the true marginal cost of educating an additional student. Thus, an increase seems warranted. Moreover, one would expect, and welcome from a welfare-theoretic point of view, a stronger differentiation of fees across universities and across fields of study, so as to reflect differences in quality and production costs.

\footnotetext{
${ }^{16}$ Sources: Statistisches Bundesamt (2007a, Table 1.4; 2007b, Table ZUS-06), own calculations.

${ }^{17}$ Lüdeke and Beckmann (1998, Table 1, p. 10).
} 
As a more fundamental conclusion, the analysis presented here suggests that there is nothing inherently wrong with decentralised policy in higher education. Following Tiebout's insight, an excludable good, which higher education certainly is, can be provided by competing jurisdictions in an efficient way if users can be charged accordingly. For a long time, the German system, until recently characterised by federal regulation of state universities and a ban on tuition fees, did not nearly conform to this ideal. Rather, the current state of German universities may serve as an example for the consequences of the general structural deficit of German federalism: States are quite autonomous in their spending decisions, but do not have the right to decide on their own revenues - be it tuition, in the case of universities, or taxes, for all kinds of public goods provided by states. Since revenue-raising and spending authority are out of line, states do not face the correct incentives, and hardly take efficient decisions. Germany will have a long way to go so as to bridge this gap, but, with recent reforms in higher education, at least has started on this journey.

\section{References}

Buchanan, J., 1965. An economic theory of clubs. Economica 32, 1-14.

Bundesministerium der Finanzen, 2006. Monatsbericht des BMF, August 2006. Downloadable from http://www.bundesfinanzministerium.de/lang_de/ DE/Aktuelles/Monatsbericht__des__BMF/2006/08/060816agmb003.html

Bundesministerium für Bildung und Forschung, 2007. Schavan: Mehr Autonomie für die Hochschulen in Deutschland: Kabinett beschließt Aufhebung des Hochschulrahmengesetzes. Pressemitteilung 098/2007, 9. Mai 2007. Downloadable from http://www.bmbf .de/press/2044.php

Büttner, T., M. Kraus, and J. Rincke, 2003. Hochschulranglisten als Qualitätsindikatoren im Wettbewerb der Hochschulen. Vierteljahreshefte zur Wirtschaftsforschung 72 , 252-270.

Büttner, T. and R. Schwager, 2004. Regionale Verteilungseffekte der Hochschulfinanzierung und ihre Konsequenzen. In: W. Franz, H.J. Ramser, and M. Stadler (eds.), Bildung. Tübingen: Mohr-Siebeck, 251-278.

CHE and Stifterverband (ed.), 1998. Modell für einen Beitrag der Studierenden zur Finanzierung der Hochschulen (Studienbeitragsmodell). Gütersloh and Essen. 
CHE and Stifterverband (ed.), 1999. InvestiF und GefoS - Modelle der individuellen und institutionellen Bildungsfinanzierung im Hochschulbereich. Gütersloh and Essen.

Epple, D. and R. Romano, 1998. Competition between private and public schools, vouchers, and peer group effects. American Economic Review 88, 33-62.

Fabel, O., E. Lehmann, and S. Warning, 2002. Der relative Vorteil deutscher wirtschaftswissenschaftlicher Fachbereiche im Wettbewerb um studentischen Zuspruch: Qualität des Studiengangs oder des Studienortes? Zfbf - Schmalenbachs Zeitschrift für betriebswirtschaftliche Forschung 54, 509-526.

Kemnitz, A., 2005. Educational federalism and the quality effects of tuition fees. Mimeo, Universität Mannheim.

Kraus, M., 2004. Schätzung von Kostenfunktionen für die bundesdeutsche Hochschulausbildung: Ein konzeptioneller Ansatz im empirischen Test. ZEW Discussion Paper 04-36, Mannheim.

Lüdeke, R. and K. Beckmann, 1998. Social costs of higher education: Production and financing - The case of Germany (1994). Mimeo, Universität Passau.

Miceli, T., 1993. The decision to regionalize in the provision of education: An application of the Tiebout model. Journal of Urban Economics 33, 344-360.

Nechyba, T., 1999. School finance induced migration and stratification patterns: The impact of private school vouchers. Journal of Public Economic Theory 1, 5-50.

Poutvaara, P., 2004. Educating Europe: Should public education be financed with graduate taxes or income-contingent loans? CESifo Economic Studies 50, 663-684.

Poutvaara, P., 2005. Public education in an integrated Europe: Studying to migrate and teaching to stay? ZEI Working Paper B 03, 2005, Universität Bonn.

Schweizer, U., 1996. Endogenous fertility and the Henry George Theorem. Journal of Public Economics 61, 209-228.

Starrett, D., 1988. Foundations of public economics. Cambridge: Cambridge University Press.

Statistisches Bundesamt, 2007a. Bildung und Kultur: Finanzen der Hochschulen. Fachserie 11, Reihe 4.5, 2005. Wiesbaden. 
Statistisches Bundesamt, 2007b. Bildung und Kultur: Studierende an Hochschulen. Fachserie 11, Reihe 4.1, Wintersemester 2005/2006. Wiesbaden.

Tiebout, C., 1956. A pure theory of local expenditures. Journal of Political Economy 64, 416-424.

Wildasin, D., 2000. Labor market integration, investment in risky human capital, and fiscal competition. American Economic Review 90, 73-95. 